\title{
An analysis of the biofilms adhered to framework alloys using in vitro denture plaque models
}

\author{
Yu URUSHIBARA 1 , Tomoko OHSHIMA², Maki SATO ${ }^{1}$, Yoshiko HAYASHI ${ }^{3}$, Tohru HAYAKAWA ${ }^{4}$, Nobuko MAEDA² \\ and Chikahiro OHKUBO ${ }^{1}$ \\ ${ }^{1}$ Department of Removable Prosthodontics, Tsurumi University School of Dental Medicine, 2-1-3 Tsurumi, Tsurumi-ku, Yokohama, Kanagawa 230- \\ 8501, Japan \\ ${ }^{2}$ Department of Oral Microbiology, Tsurumi University School of Dental Medicine, 2-1-3 Tsurumi, Tsurumi-ku, Yokohama, Kanagawa 230-8501, \\ Japan \\ ${ }^{3} R$ \& D Department, Sunstar Inc., 5-30-1, Kamihamuro, Takatsuki, Osaka, 569-1044, Japan \\ ${ }^{4}$ Department of Dental Engineering, Tsurumi University School of Dental Medicine, 2-1-3 Tsurumi, Tsurumi-ku, Yokohama, Kanagawa 230- 8501, \\ Japan \\ Corresponding author, Yu URUSHIBARA; E-mail: urushibara-yuu@tsurumi-u.ac.jp
}

\begin{abstract}
The purpose of this study was to perform a quantitative and qualitative evaluation of the biofilms formed on framework alloys in vitro. The biofilms formed by unfiltered fresh human saliva or Streptococcus mutans and/or Candida albicans on commercially pure titanium and gold-copper-platinum demonstrated higher amounts than other alloy and resin samples. In contrast, the silverpalladium-copper-gold showed a significantly decreased level of biofilm formation. Although the adhesion level of Streptococcus mutans on cobalt-chromium was high, that of Candida albicans was less extensive. A T-RFLP analysis and qualitative PCR of the microbes in the biofilms were performed. In a cluster analysis of all T-RFLP profiles, the cobalt-chromium pattern was integrated into one cluster. On qualitative PCR, the existence of microorganisms related to caries, preriodontitis and aspiration pneumonia was observed. Our results showed that the biofilm formation on each framework alloy was different in terms of both the quantity and quality.
\end{abstract}

Keywords: Framework alloy, Denture plaque, T-RFLP, Microbiota

\section{INTRODUCTION}

The wearing of removable dentures can lead to the colonization of oral pathogenic bacteria and/or poor oral hygiene ${ }^{1-3)}$. Dentures become a reservoir for dental plaque, which can cause local and systemic disease ${ }^{4-6)}$. The health population movement statistics in Japan (2011) showed that the incidence of pneumonia has been increasing as the cause of death in Japan, and now exceeds cerebrovascular disease ${ }^{7)}$.

The major pathogenic bacteria associated with aspiration pneumonia are oral bacteria, particularly Peptostreptococcus, Prevotella and Fusobacterium ${ }^{8)}$. Aspiration pneumonia is also caused by denture plaque ${ }^{5,6,9)}$ that contains the same anaerobic bacteria, such as Prevotella and Fusobacterium ${ }^{9}$. Oral care, with a focus on oral hygiene to reduce the dental plaque, can help decrease the incidence of pneumonia ${ }^{10,11)}$. Among the microorganisms present in denture plaques, Candida albicans (C. albicans) and Streptococcus mutans ( $S$. mutans) are well known as pathogens causing oral infections ${ }^{2,12-16)}$. The level of C. albicans increases in the oral cavity following the insertion of dentures, and can cause denture stomatitis, aspiration pneumonia and intestinal infections ${ }^{2,12-14)}$. S. mutans is a caries-causing oral Streptococci ${ }^{15,16)}$, and is associated with inducing dental caries on the remaining teeth in the oral cavity of denture wearers.

Denture plaque easily adheres to the resin denture base ${ }^{17)}$, because the surface of the acrylic resin is porous. Another problem associated with resin dentures is their weak mechanical strength when compared to metal base dentures. Metal base dentures have excellent mechanical strength ${ }^{18)}$. Cobalt-chromium alloy (Co-Cr) is mainly used for the metal framework of removable dentures. Recently, commercially pure titanium (CP Ti) and titanium alloys (Ti 6-7) have been used as the metal framework of removable dentures ${ }^{19)}$. Titanium has excellent biocompatibility, low allergic potential ${ }^{20,21)}$, lower thermal conductivity and greater laser beam absorption than other metal alloys ${ }^{22)}$, making it an ideal material for dentures and other medical appliances.

There have been some reports of the quantitative evaluation of adhesion plaques and the qualitative bacterial colonization on the metal materials used for prostheses ${ }^{23,24)}$. For example, Yamane et al. investigated the bacterial adhesion affinities on various implant abutment materials ${ }^{23)}$. They concluded that Au-Pt alloy accumulated less plaque than other materials. On the other hand, there have been no reports that have performed both quantitative and qualitative studies of the adhered biofilms on various framework alloys.

The purposes of this study were to analyze the biofilms adhered to the framework alloys both in quality and quantity of microbiota, and to compare each alloy and conventional resin. 


\section{MATERIAL AND METHODS}

Fabrication of alloy samples

The rectangular alloy samples $(20.0 \times 12.0 \times 1.4 \mathrm{~mm})$ were cast using the materials shown in Table 1 . The surface of each alloy sample was polished to be a mirror-smooth surface in accordance to the polishing procedure used by the Tsurumi University Hospital Laboratory Center ${ }^{25)}$, and was sterilized by an autoclave. As a control, the same size of resin sample was prepared with polymethyl methacrylate (PMMA) self-curing denture base resin (resin, Palapress vario, Heraeuskulzer, Hanau, Germany), sterilized with $80 \%$ ethanol, which was immersed in distilled water for $24 \mathrm{~h}$.

\section{Measurement of the surface properties}

The average surface roughness of all samples was measured with a non-contact coordinate measuring machine (NH-4H, Mitaka Kohki Co., Ltd., Mitaka, Japan). The surface contact angle an index of hydrophilicity, was also measured using a contact anglemeasuring apparatus (CA-P, Kyowa Interface Science Co., Ltd., Niiza, Japan).

Observation of the surface of the samples

The surface of the samples after being immersed in the filtered saliva overnight was observed using a scanning electron microscope (SEM; JSM-5600LV, JEOL Ltd., Akishima, Japan) and an electron prove microanalyzer (EPMA: JXA-8900RL, JEOL Ltd). Only resin samples were sputter-coated with gold to a thickness of approximately $250 \AA$ in a vacuum evaporator.

Preparation and cultivation of biofilm-adhered samples In order to make an in vitro denture plaque model using the framework alloys and resin, biofilms were formed on each sample using human saliva. Stimulated human saliva was collected by the chewing gum method from volunteer subjects, and was divided into non-filtered and filtered samples. The study protocol was approved by the ethics committee of Tsurumi University (permission no. 1040), and all volunteers provided informed consent for their participation. The subjects who had untreated dental caries, removable dentures or periodontitis were excluded. The selected subjects were five adult healthy males between 29 and 31 years old who had not used any antibiotics for the past three months.

Fifteen samples of each alloy were immersed immediately in the non-filtered human saliva and were continuously incubated under aerobic conditions at $37^{\circ} \mathrm{C}$ overnight to allow early biofilms to form on the samples (Fig. 1). On the second day, the samples were removed from the saliva and immersed in brain-heart infusion broth (BHI; Difco, Becton, Dickinson and Company, Sparks, MD, USA) for the maturation of the biofilms. The BHI broth was replaced every day until the seventh day.

Preparation of biofilms with S. mutans or C. albicans The precultures of $S$. mutans and $C$. albicans were

Table 1 The materials used in this study, their composition and their surface properties

\begin{tabular}{|c|c|c|c|c|c|c|c|}
\hline & \multirow{2}{*}{ Abbreviation } & \multirow{2}{*}{$\begin{array}{c}\text { Trade name / } \\
\text { distribution source }\end{array}$} & \multirow{2}{*}{ Element, wt\% } & \multicolumn{2}{|c|}{ Surface roughness $(\mu \mathrm{m})$} & \multicolumn{2}{|c|}{ Contact angle $\left(^{\circ}\right)$} \\
\hline & & & & Uncoated & Saliva-coated & Uncoated & Saliva-coated \\
\hline $\begin{array}{l}\text { Commercially pure } \\
\text { titanium }\end{array}$ & $\mathrm{CP} \mathrm{Ti}$ & $\begin{array}{c}\text { T-alloy H / GC Corp., } \\
\text { Tokyo, Japan }\end{array}$ & Ti, 99.2 & $0.045 \pm 0.009$ & $0.044 \pm 0.008$ & $93.5 \pm 2.1$ & $36.0 \pm 4.7$ \\
\hline Titanium alloy & Ti 6-7 & $\begin{array}{l}\text { T-alloy Tough / } \\
\text { GC Corp., } \\
\text { Tokyo, Japan }\end{array}$ & $\begin{array}{l}\mathrm{Ti}, 86.5 \\
\mathrm{Nb}, 7.0 \\
\mathrm{Al}, 6.0\end{array}$ & $0.040 \pm 0.008$ & $0.042 \pm 0.005$ & $93.5 \pm 1.8$ & $35.2 \pm 3.3$ \\
\hline $\begin{array}{l}\text { Cobalt-chromium } \\
\text { alloy }\end{array}$ & $\mathrm{Co}-\mathrm{Cr}$ & $\begin{array}{l}\text { Wisil M / Elephant } \\
\text { Dental B.V., } \\
\text { Hoorn, Netherland }\end{array}$ & $\begin{array}{l}\text { Co, 63.1; } \\
\text { Cr, 28.0; } \\
\text { Mo, } 6.0\end{array}$ & $0.044 \pm 0.011$ & $0.048 \pm 0.007$ & $93.6 \pm 2.5$ & $34.4 \pm 3.6$ \\
\hline $\begin{array}{l}\text { Silver-palladium- } \\
\text { copper-gold alloy }\end{array}$ & $\mathrm{Ag}-\mathrm{Pd}-\mathrm{Au}$ & $\begin{array}{l}\text { Kinparabest12 / } \\
\text { Ishifuku, } \\
\text { Tokyo, Japan }\end{array}$ & $\begin{array}{l}\mathrm{Ag}, 49.5 \\
\mathrm{Pd}, 20.0 \\
\mathrm{Cu}, 19.0 \\
\mathrm{Au}, 12.0\end{array}$ & $0.035 \pm 0.005$ & $0.038 \pm 0.008$ & $93.2 \pm 3.4$ & $32.4 \pm 2.6$ \\
\hline $\begin{array}{l}\text { Gold-copper- } \\
\text { platinum alloy }\end{array}$ & PGA & $\begin{array}{l}\text { PGA-3 / Ishifuku, } \\
\text { Tokyo, Japan }\end{array}$ & $\begin{array}{c}\mathrm{Au}, 70.0 \\
\mathrm{Cu}, 19.0 \\
\mathrm{Ag}, 4.7 \\
\mathrm{Pt}, 6.0\end{array}$ & $0.035 \pm 0.008$ & $0.038 \pm 0.007$ & $95.9 \pm 2.6$ & $33.2 \pm 1.8$ \\
\hline Denture base resin & resin & $\begin{array}{l}\text { Palapress vario / } \\
\text { Heraeus-kulzer, } \\
\text { Hanau, Germany }\end{array}$ & $\begin{array}{l}\text { Polymethyl } \\
\text { methacrylate }\end{array}$ & $0.082 \pm 0.008$ & $0.082 \pm 0.013$ & $70.4 \pm 3.0$ & $34.0 \pm 4.0$ \\
\hline
\end{tabular}




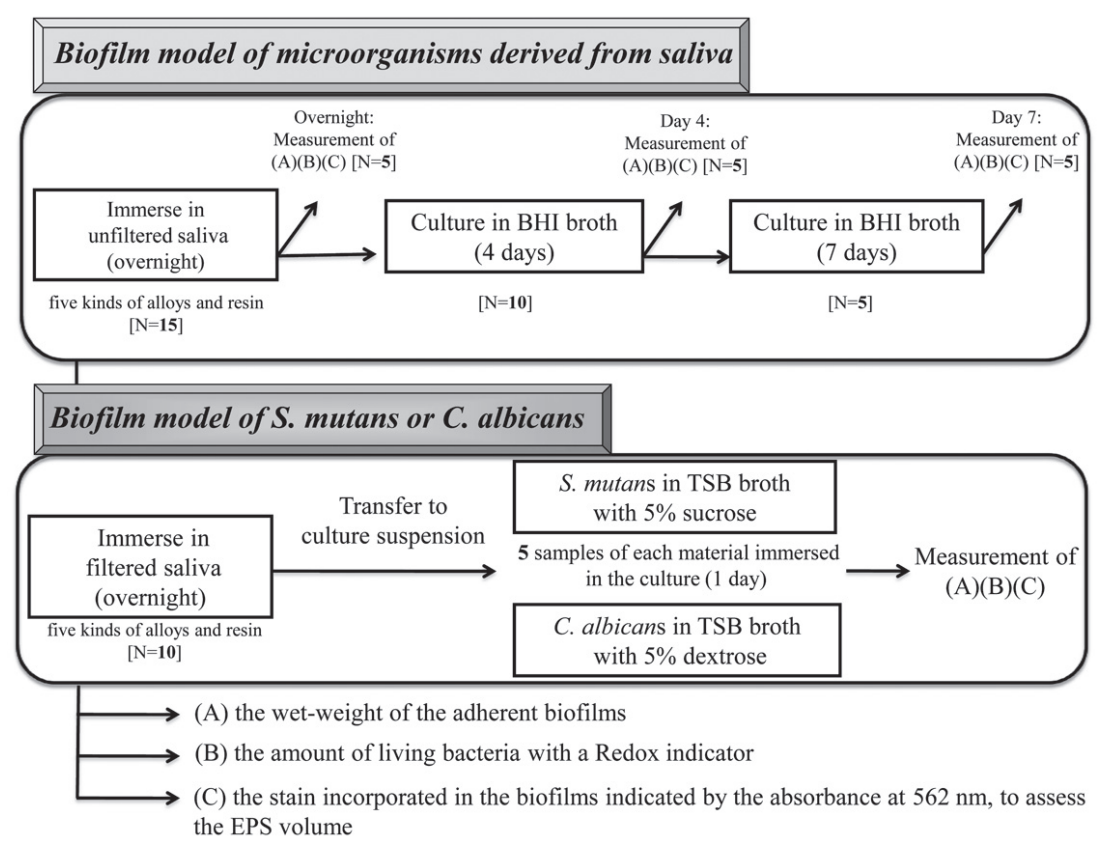

Fig. 1 Preparation and cultivation of in vitro denture plaque models, and measurement of the biofilm levels.

carried out as follows: S. mutans ATCC25175 was precultured in brain-heart infusion broth (BHI; Difco, Becton, Dickinson and Company, Sparks, MD, USA) at $37^{\circ} \mathrm{C}$ in an anaerobic chamber. An aliquot of the S. mutans culture was inoculated into $10 \mathrm{~mL}$ of $\mathrm{BHI}$. The number of $S$. mutans cells was approximately $1 \times 10^{7}$ to $1 \times 10^{8} \mathrm{CFU} / \mathrm{mL}$. C. albicans ATCC18804 was precultured in tryptic soy broth supplemented with $5 \%$ dextrose (TSBD; Difco, Becton, Dickinson and Company) medium at $37^{\circ} \mathrm{C}$ with aerobic shaking. An aliquot of 300 $\mu \mathrm{L}$ of the precultured $C$. albicans was inoculated into $3 \mathrm{~mL}$ of TSBD. The number of $C$. albicans cells was approximately $1 \times 10^{6}$ to $1 \times 10^{7} \mathrm{CFU} / \mathrm{mL}$.

For the quantitative analysis of biofilms formed by $S$. mutans or C. albicans, ten samples of each alloy was immersed in the filtered pooled saliva overnight at $4^{\circ} \mathrm{C}$ (Fig. 1). The samples were divided into two groups, five samples were immersed in $S$. mutans culture solution, and the other five samples were immersed in C. albicans culture solution for one day.

Measurement of the wet-weight, living bacteria and extracellular polysaccharide (EPS) in biofilms

As shown in Fig. 1, on the first, fourth and seventh days of cultivation, five samples of each alloy or resin were taken from the media, and the wet-weight was measured after removing the excess media. Each sample was then incubated in RPMI 1640 medium supplemented with $10 \%$ FBS and a REDOX indicator (Alamar blue; Trek Diagnostic Systems, Cleveland, OH, USA) at $37^{\circ} \mathrm{C}$ to estimate the amount of living bacteria present in the biofilm. The amount of living bacteria in the biofilm was determined based on the fluorescence levels (EX: 530 $\mathrm{nm}$, EM: $590 \mathrm{~nm}$ ) using a fluorescent microplate reader, the Cyto-Fluor 2 (Per Septive Biosystems, Farmingham, MA, USA). The cultivation was stopped when the fluorescence of the sample reached a value of 30,000 .

Following the estimation of the amount of living bacteria, the amount of EPS was determined by dental plaque staining (Dent liquid plaque tester, LION Co., Ltd., Tokyo, Japan). The stain-incorporated EPS was extracted with $99.9 \%$ ethanol, and the optical density of the extracts was measured using an absorbance meter (UV-1200, SHIMADZU Co., Ltd., Kyoto, Japan) at OD562 $\mathrm{nm}$ to examine the quantity of $\mathrm{EPS}^{26)}$.

The same quantitative analyses were also performed for the biofilms formed by $S$. mutans or $C$. albicans on five samples of each alloy or resin after overnight cultivation.

\section{The terminal restriction fragment length polymorphism (T-RFLP) analysis}

To perform a T-RFLP analysis of the biofilms, each alloy or resin sample was incubated with fresh unfiltered individual saliva $(n=5)$ overnight. Each sample was washed in distilled water three times to remove nonadherent microbial cells. The genomic DNA was extracted from each of the samples, and from individual saliva samples, with the QIAamp DNA Mini Kit (QIAGEN, Tokyo, Japan), and was stored at $-20^{\circ} \mathrm{C}$.

The internal regions of $16 \mathrm{~S}$ rRNA genes were amplified from genomic DNA using the universal forward primer, FAM (5'-AGA GTT TGA TYM TGG CTC AG-3'), labeled at the 5' end with 6-carboxyfluorescein 
(6- FAM) and the universal reverse primer, HEX (5'GGA CTA CCR GGG TAT CRA A -3'), labeled at the 5' end with hexachlorofluorescein. The PCR was performed with $5 \mu \mathrm{L}$ of sample added to $45 \mu \mathrm{L}$ of reaction mixture containing $5 \mu \mathrm{L} 10 \times \mathrm{Ex}$ taq buffer (TaKaRa EX Taq, TaKaRa Bio Company, Ohtsu, Japan), $0.25 \mu \mathrm{L} 5 \mathrm{U} / \mu \mathrm{L}$ Taq polymerase (TaKara ExTaq, TaKaRa Bio Company) and $20 \mathrm{pmol} / \mu \mathrm{L}$ of each of primer. PCR amplification was performed in a thermal cycler (PCR Thermal Cycler MP, TaKaRa Bio Company). The PCR temperature profile was an initial denaturation step at $95^{\circ} \mathrm{C}$ for 2 min, followed by 30 cycles of denaturation at $95^{\circ} \mathrm{C}$ for $20 \mathrm{~s}$, annealing at $55^{\circ} \mathrm{C}$ for $30 \mathrm{~s}$ and extension at $72^{\circ} \mathrm{C}$ for $1.5 \mathrm{~min}$, and final step of $72^{\circ} \mathrm{C}$ for $10 \mathrm{~min}$.

The PCR amplification, purification and digestion with Hae III, Hha I and Msp I were conducted as described previously ${ }^{27}$. The restriction digest products were denatured, electrophoresed and analyzed using the GeneMapper software program, version 4.0 (Applied Biosystems, Foster City, CA, USA). Terminal restriction fragments with peak areas $<0.5 \%$ of the total area were eliminated from the analysis.

\section{Qualitative PCR for oral microorganisms}

Qualitative PCR was carried out according to the previous studies ${ }^{28-40}$ using DNA templates extracted from the biofilms on five alloys, resin and the individual saliva samples $(N=5)$. The primers used were for the genera of Actinomyces ${ }^{28)}$, Burkholderia ${ }^{29)}$, Fusobacterium $^{30)}$, Haemophilus ${ }^{31)}$, Mycoplasma ${ }^{32}$, Neisseria $^{33)}$, Peptostreptococcus ${ }^{34)}, \quad$ Pseudomonas ${ }^{35)}$, Streptococcus ${ }^{36)}$, Staphylococcus ${ }^{37)}$, and Candida ${ }^{38)}$ and for the species of Aggregatibacter actinomycetemcomitans, Porphyromonas gingivalis, Prevotella intermedia, Treponema denticola, Tannerella forsythia ${ }^{39)}$ and $S$. mutans ${ }^{40)}$.

\section{Statistical analysis}

The surface properties (surface roughness and contact angle) were analyzed using a one-way analysis of variance (ANOVA) and Tukey's test, with a significance level set at $\alpha=0.05$. The statistical analyses of the quantitative analyses of the biofilms were performed for multiple groups using the Kruskal-Wallis test, and between two groups using a Mann-Whitney U-test, with the significance level set at $a=0.05$. A cluster analysis was performed using Ward's algorithm (SPSS 14.0, IBM Japan, Ltd., Tokyo, Japan). The dissimilarity analysis of the T-RFLP data was carried out with a Bray-Curtis analysis (SYSTAT13, Systat Software, Inc., Chicago. IL, USA).

\section{RESULTS}

Measurement of the surface properties

The surface roughness and contact angle of each sample coated with filtered saliva was within the range of surface roughness $0.04-0.05 \mu \mathrm{m}$ and contact angle $32-$ $36^{\circ}$, respectively. There were no significant differences in the surface roughness and contact angle among the five alloys, except for the control resin (surface roughness $0.08 \mu \mathrm{m}$, contact angle $34^{\circ}$ ). The contact angle of the samples with saliva coating was significantly decreased (Table 1).

\section{Observation of the surface of each sample}

The samples coated with the filtered saliva were observed by SEM and EPMA. The surface of each sample in SEM was different. Certain substances derived from saliva were observed on all of samples except for AgPd-Au (Fig. 2a). The intensity on the surface of the gold-copper-platinum alloy (PGA) in EPMA images of calcium was higher in comparison to the other samples (Fig. 2b).

\section{Quantitative analysis of the biofilms}

The levels of biofilm adherence to each sample was determined based on three parameters; the wet-weight, the activity of living bacteria and the amount of EPS in the biofilm. The results of these analyses are shown in Fig. 3. The amounts of adherent biofilm in all of three assays increased during the incubation in a time-dependent manner. The determination of living bacterial activity was measured when the redox indicated reached its maximum value (approximately 30,000-40,000), which was after $15 \mathrm{~h}$ of incubation for overnight culture, $5 \mathrm{~h}$ of incubation after a 4 -day culture and $3 \mathrm{~h}$ of incubation after a 7-day culture. PGA and CP Ti showed higher adherence levels than did the other alloys and resin. There were significant differences in the adherence levels between PGA or $\mathrm{CP} \mathrm{Ti}$ and resin after both the overnight and 4-day incubations $(p<0.05)$.

In contrast, $\mathrm{Ag}-\mathrm{Pd}-\mathrm{Au}$ showed a significantly lower value compared with the other alloys $(p<0.05)$. On day 7 , there were no significant differences in the amount of adherent biofilm among the alloys and resin, except for the Ag-Pd-Au alloy, which was significantly lower than the other samples $(p>0.05)$.

The SEM images showed the biofilm that adhered to the CP Ti to have formed several layers by day 7 (Fig. 4).

\section{Analysis of the microbial components by T-RFLP}

The total biofilm was recovered from each sample after overnight cultivation with individual saliva samples, and DNA was extracted to perform a T-RFLP analysis. Figure 5 shows the peak area of the T-RF with the HaeIII restriction enzyme, which was more than $1 \%$ of the total area. Peak area 33 was the major peak for all of the alloys. In this peak area, PGA showed the highest ratio, which was approximately $65 \%$, and $\mathrm{Co}-\mathrm{Cr}$ had the lowest, at $25 \%$. Co-Cr showed a larger ratio than the other alloys for peak areas 60 and 68. Peak area 84 was the highest on Ag-Pd-Au among all of the alloys.

Figure 6 shows the profiles of T-RFLP as indicated by the cluster analysis. All samples were categorized into two main clusters (clusters I and II). Although the T-RFs of all five $\mathrm{Co}-\mathrm{Cr}$ samples were classified into cluster I, four of the five PGA samples were classified into cluster II. Three samples of CP Ti, Ti 6-7 and resin 
a)

CP Ti

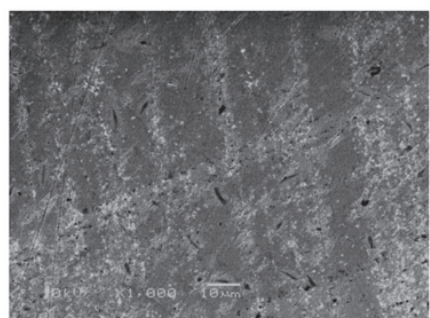

Ag-Pd-Au

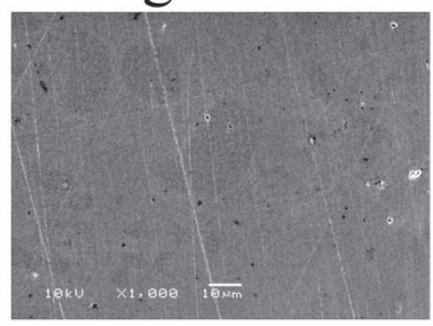

b)

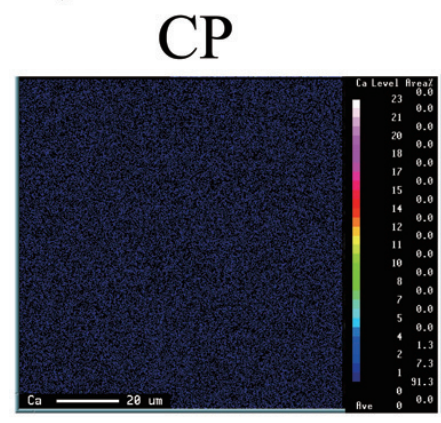

Ag-Pd-Au

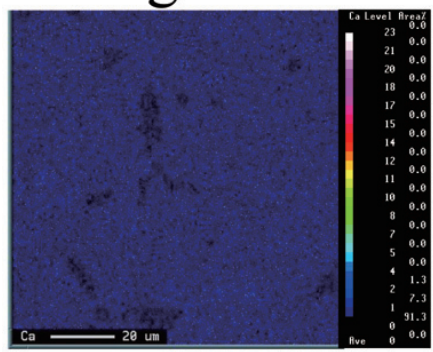

Ti 6-7

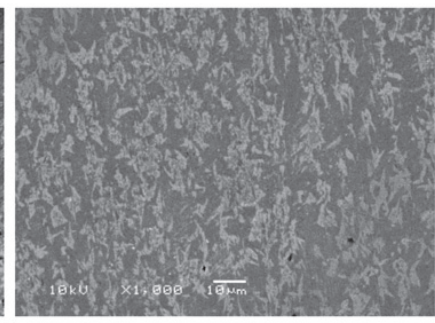

PGA

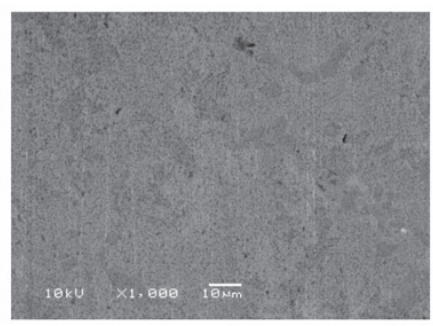

$\mathrm{Co}-\mathrm{Cr}$

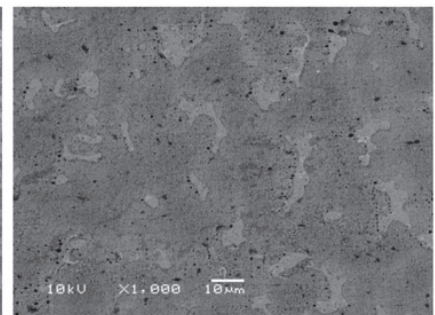

resin

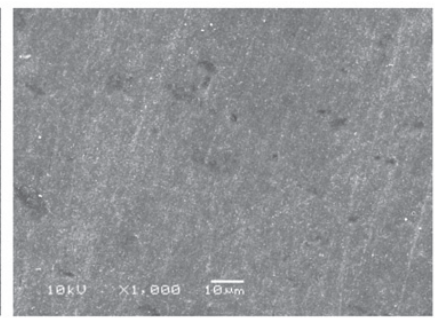

Fig. 2 a) The surface of each sample coated with the filtrated saliva observed by SEM b) EPMA image of calcium (color bar: X-ray intensity of calcium).

were classified into cluster I, and the other two samples belonged to cluster II. The profiles of CP Ti, Ti 6-7, resin and the saliva samples (subject Nos. 1, 2, 4, 5) were closely grouped, and they were consequently classified in the same cluster, except for saliva sample No 3.

When a Bray-Curtis analysis was performed to compare the similarity of the T-RFLP profiles, CP Ti/ Ti 6-7, CP Ti/resin, and $\mathrm{Ti}$ 6-7/resin showed higher 


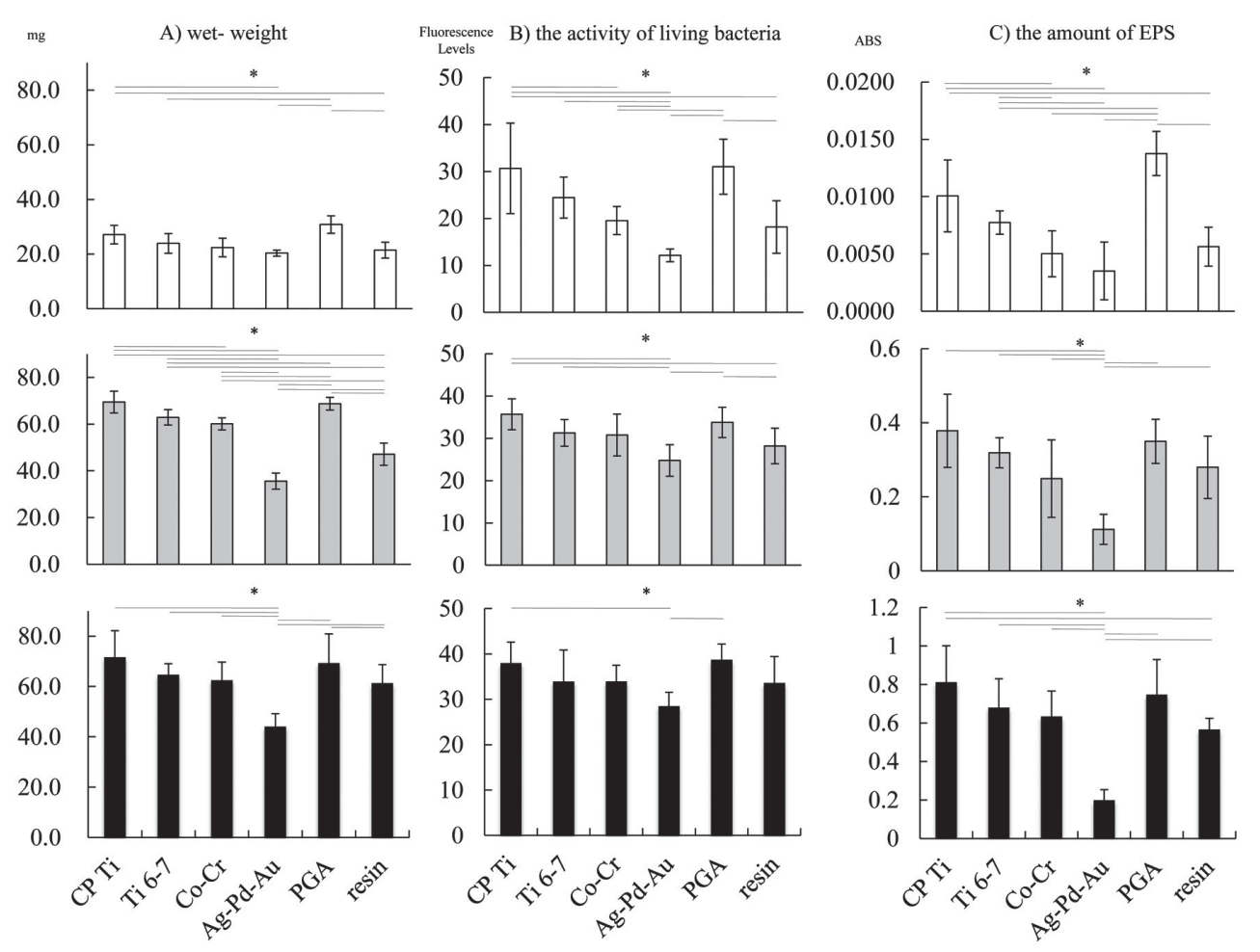

Fig. 3 Determination of the amount of biofilm adhered to each alloy.

The wet-weight of the adherent biofilm, the activity of living bacteria and the amount of dye inclusion were measured to assess the levels of biofilm adherence. The asterisk indicates a significant difference (Mann-Whitney U-test, $p<0.05$ ).

A: The wet-weight of the adherent biofilm; the vertical axis shows the increase in the weight, B: The activity of living bacteria; the vertical axis shows the fluorescence level of the metabolized redox indicator $(\times 1000)$, C: The amount of EPS, indicating the levels of biofilm adherence; the vertical axis shows the absorbance at $562 \mathrm{~nm}$, after overnight culture in saliva (white bar), four days of culture in BHI after the overnight culture in saliva (gray bar) and seven days of culture in BHI after the overnight culture in saliva (black bar).

$\mathrm{CP} \mathrm{Ti}$

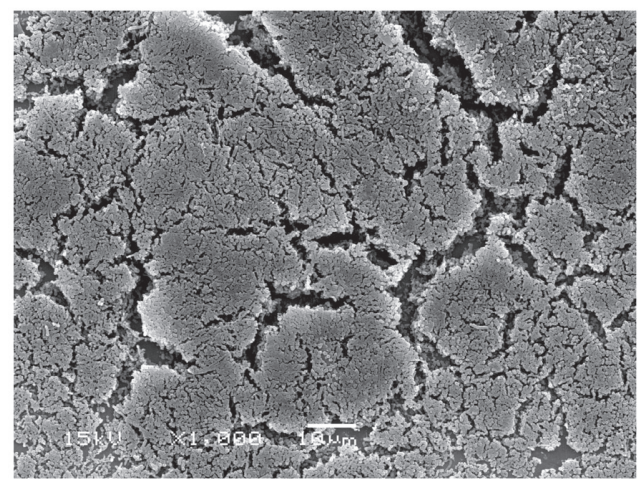

Ag-Pd-Au

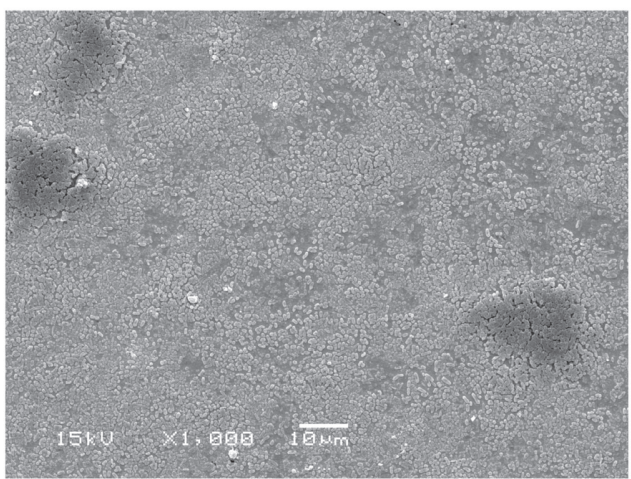

Fig. 4 The SEM images of biofilms on the CP Ti and Ag-Pd-Au at day 7. 


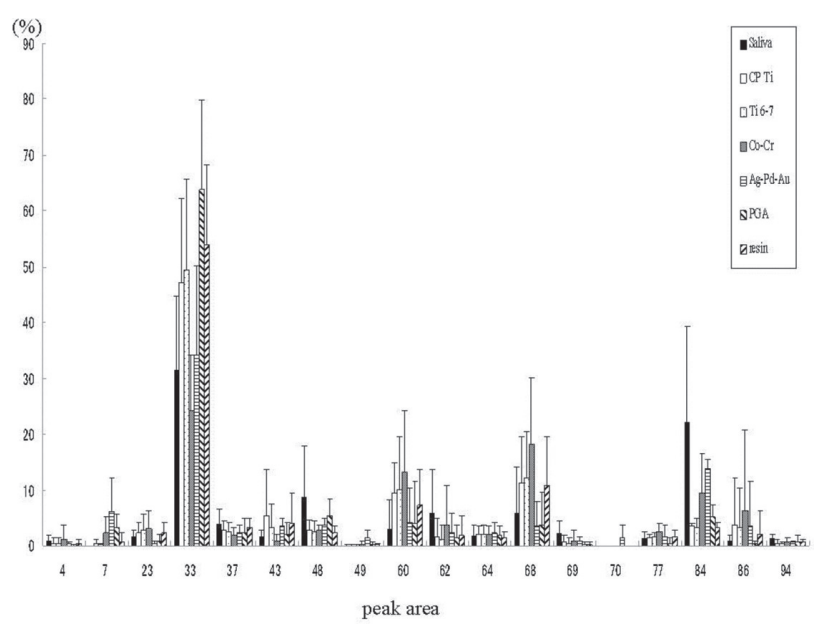

Fig. 5 The T-RFLP peak distribution of the alloy, resin and saliva samples.

The bars demonstrate the average levels of the peak areas of the T-RFs with Hae III. The cut-off value was set at $1 \%$.

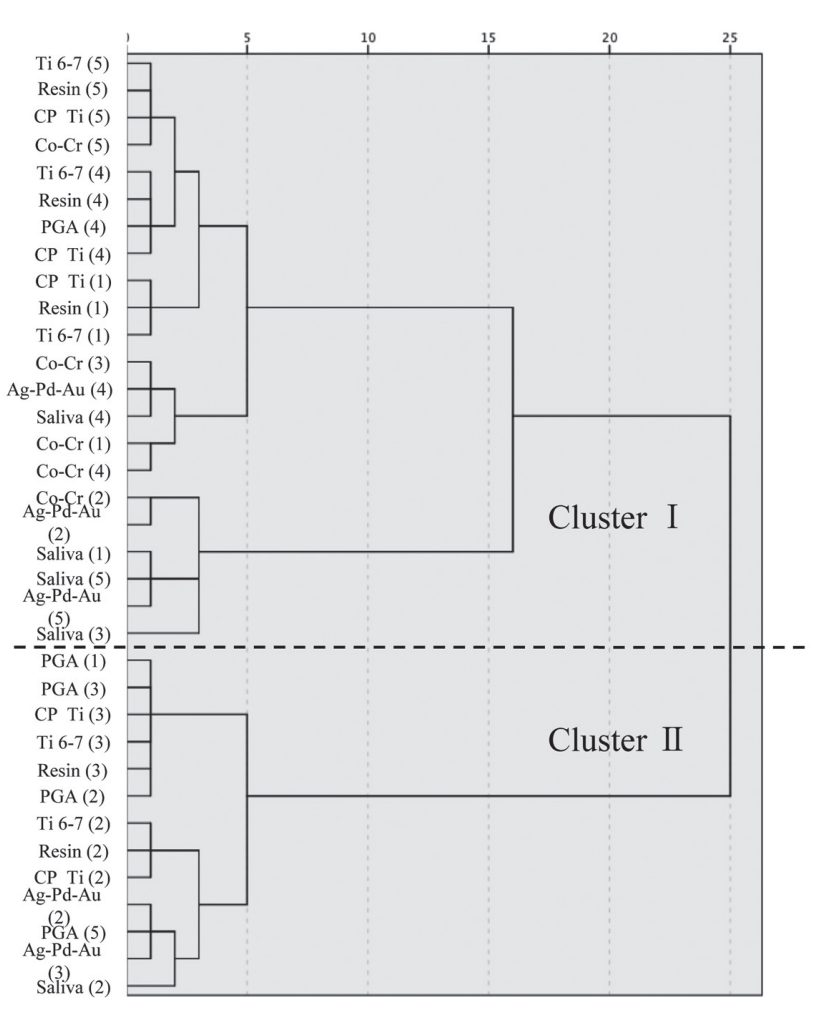

Fig. 6 The results of the cluster analysis of the T-RFLP pattern for all samples.

The T-RFLP patterns of Hae III, Hha I and Msp I were analyzed by the Ward method.

( ): subject numbers.

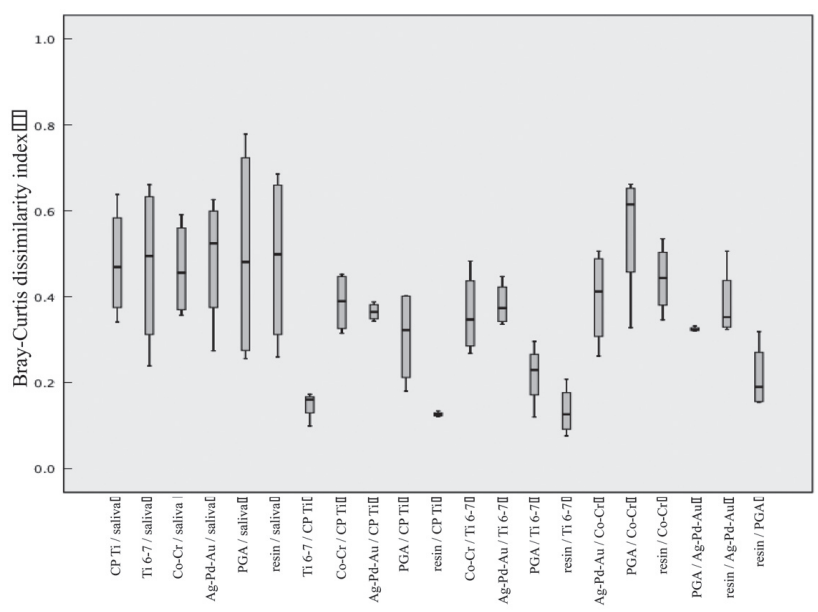

Fig. 7 The Bray-Curtis dissimilarity of the T-RFLP profiles.

The differences between various sets of two types of samples are shown.

similarity, at levels of around 0.14, as shown in Fig. 7 (indicating that they were very similar). These results were consistent with the distance between the clades in the cluster analysis. In contrast, the similarity of $\mathrm{Co}-\mathrm{Cr}$ and PGA in the different clusters showed a lower level $(0.52$, not very similar).

\section{Qualitative PCR}

The T-RFLP analysis was performed with three enzyme; Hae III, Hha I and Msp I in this study. The T-RFs which showed a more than $10 \%$ peak level for all of three enzymes were selected to predict the genus of the microorganisms based on a database ${ }^{41}$.

To confirm these findings, a qualitative PCR analysis was carried out using genus- and species-specific primers. The genera of Actinomyces, Burkholderia, Fusobacterium, Haemophilus, Mycoplasma, Neisseria Peptostreptococcus, Pseudomonas, Staphylococcus and Streptococcus were detected in the template DNA of the saliva samples (Table 2). On the contrary, genera of Actinomyces, Fusobacterium, Haemophilus, Mycoplasma and Peptostreptococcus were found in the template DNA of the biofilms on five alloys and resin. Burkholderia, Pseudomonas and Staphylococcus were detected in the saliva samples, but not in the five alloy and resin samples. This suggested that these three genera did not adhere to the five alloys or resin after overnight culture.

The template DNA samples in the biofilms on the five alloys and resin showed evidence of periodontal disease-causing microorganisms, including $T$. denticola, T. forsythia, $P$. gingivalis, $P$. intermedia and also the cariogenic bacteria, S. mutans. The binding properties or affinities of Mycoplasma, $P$. gingivalis and T. denticola for the five alloys and resin were not equal (Table 2). 
Table 2 The qualitative PCR detection of candidate genus and species in the saliva and plaques adhered to five alloys and resin

\begin{tabular}{|c|c|c|c|c|c|c|c|}
\hline PCR detection & Saliva & $\mathrm{CP} \mathrm{Ti}$ & Ti 6-7 & $\mathrm{Co}-\mathrm{Cr}$ & Ag-Pd-Au & PGA & resin \\
\hline \multicolumn{8}{|l|}{ Genus-specific primers } \\
\hline Actinomycetale & $5 / 5$ & $5 / 5$ & $5 / 5$ & $5 / 5$ & $5 / 5$ & $5 / 5$ & $5 / 5$ \\
\hline Burkholderia & $5 / 5$ & $0 / 5$ & $0 / 5$ & $0 / 5$ & $0 / 5$ & $0 / 5$ & $0 / 5$ \\
\hline Fusobacterium & $5 / 5$ & $5 / 5$ & $5 / 5$ & $5 / 5$ & $5 / 5$ & $4 / 5$ & $5 / 5$ \\
\hline Haemophilus & $5 / 5$ & $5 / 5$ & $5 / 5$ & $5 / 5$ & $5 / 5$ & $5 / 5$ & $5 / 5$ \\
\hline Mycoplasma & $5 / 5$ & $4 / 5$ & $4 / 5$ & $4 / 5$ & $3 / 5$ & $3 / 5$ & $4 / 5$ \\
\hline Neisseria & $5 / 5$ & $5 / 5$ & $5 / 5$ & $5 / 5$ & $5 / 5$ & $5 / 5$ & $5 / 5$ \\
\hline Peptostreptoccocus & $5 / 5$ & $5 / 5$ & $5 / 5$ & $5 / 5$ & $5 / 5$ & $5 / 5$ & $5 / 5$ \\
\hline Pseudomonas & $5 / 5$ & $0 / 5$ & $0 / 5$ & $0 / 5$ & $0 / 5$ & $0 / 5$ & $0 / 5$ \\
\hline Staphylococcus & $5 / 5$ & $0 / 5$ & $0 / 5$ & $0 / 5$ & $0 / 5$ & $0 / 5$ & $0 / 5$ \\
\hline Candida & $0 / 5$ & ND & ND & ND & ND & ND & ND \\
\hline \multicolumn{8}{|l|}{ Species-specific primers } \\
\hline A. actinomycetemcomitans & ND & $0 / 5$ & $0 / 5$ & $0 / 5$ & $0 / 5$ & $0 / 5$ & $0 / 5$ \\
\hline$P$. gingivalis & ND & $2 / 5$ & $3 / 5$ & $2 / 5$ & $1 / 5$ & $1 / 5$ & $2 / 5$ \\
\hline P. intermedia & ND & $2 / 5$ & $2 / 5$ & $2 / 5$ & $2 / 5$ & $2 / 5$ & $2 / 5$ \\
\hline T. denticola & ND & $0 / 5$ & $3 / 5$ & $3 / 5$ & $1 / 5$ & $5 / 5$ & $0 / 5$ \\
\hline T. forsythia & ND & $5 / 5$ & $5 / 5$ & $5 / 5$ & $5 / 5$ & $5 / 5$ & $5 / 5$ \\
\hline S. mutans & ND & $5 / 5$ & $5 / 5$ & $5 / 5$ & $5 / 5$ & $5 / 5$ & $5 / 5$ \\
\hline
\end{tabular}

(number of positives/subject, ND: not determined)

Quantitative analysis of the initial adhesion of $S$. mutans and C. albicans on framework alloys

Prior to the quantitative analysis, the presences of $S$. mutans and $C$. albicans in the saliva samples was examined by a culture method and qualitative PCR. Candida was not detected, but $S$. mutans was found (Table 2). The adhesion levels of $S$. mutans and $C$. albicans were evaluated on the saliva-coated framework alloy samples immersed in the suspensions of $S$. mutans or C. albicans, based on the wet-weight of the biofilms, the activity of living microorganisms and the amount of EPS (Fig. 8). The adhesion levels of biofilms of both microorganisms on Ag- $\mathrm{Pd}-\mathrm{Au}$ were lower than those on the other samples. CP Ti and PGA demonstrated adhesion levels similar to or higher than those of the resin. The adherence of $S$. mutans to $\mathrm{Co}-\mathrm{Cr}$ was comparable to that on $\mathrm{CP} \mathrm{Ti}$ and PGA, but that of $C$. albicans to $\mathrm{Co}-\mathrm{Cr}$ was significantly lower than that to CP Ti and PGA.

\section{DISCUSSION}

Previous studies have suggested that dentures can become a reservoir or hotbed of plaque, and affect the systemic health of denture-wearers ${ }^{4-6)}$. However, in those reports, the material investigated was the resin denture, but not the framework alloys. To the best of our knowledge, the present study is the first to examine the plaque formation on both the denture resin and various framework alloys.

Surface properties of alloy and resin samples

A previous study of the topography on biofilm development showed that the major factors affecting bacterial adherence were the surface roughness and contact angle ${ }^{42)}$. There have been various reports about the impact of the surface roughness on the plaque adherence ${ }^{42-48)}$. It was described that the threshold surface roughness should be $0.2 \mu \mathrm{m}^{46-48)}$, and the results of the present study showed that the surface roughness of all samples was below $0.05 \mu \mathrm{m}$. There was no difference in the surface roughness between before and after saliva coating. And the level of surface roughness was almost that same among the alloy samples (Table 1). Therefore, we concluded that the surface roughness did not affect the biofilm adherence in this study. On the other hand, the contact angle in all samples without saliva coating was close to $90^{\circ}$. The contact angle in all samples with saliva coating was close to $35^{\circ}$ (Table 1 ), thus indicating that the surfaces were coated with salivary components. There was no significant difference in the contact angle among the all samples. Therefore, we concluded that the contact angle did not affect the biofilm adherence in this study.

Quantitative analysis of biofilms on the samples

To evaluate the amount of biofilm present, the wetweights of the biofilms on the samples were measured. The wet-weight reflects the biofilm volume, but might be affected by the measurement environment. Therefore, we also determined the activity of living bacteria in the biofilm and the amount of EPS in the biofilm ${ }^{26)}$, to more accurately assess the amount of biofilm.

Figure 3 shows the results of these three different quantitative analyses. The wet-weight, the activity of living bacteria and the amount of EPS were 

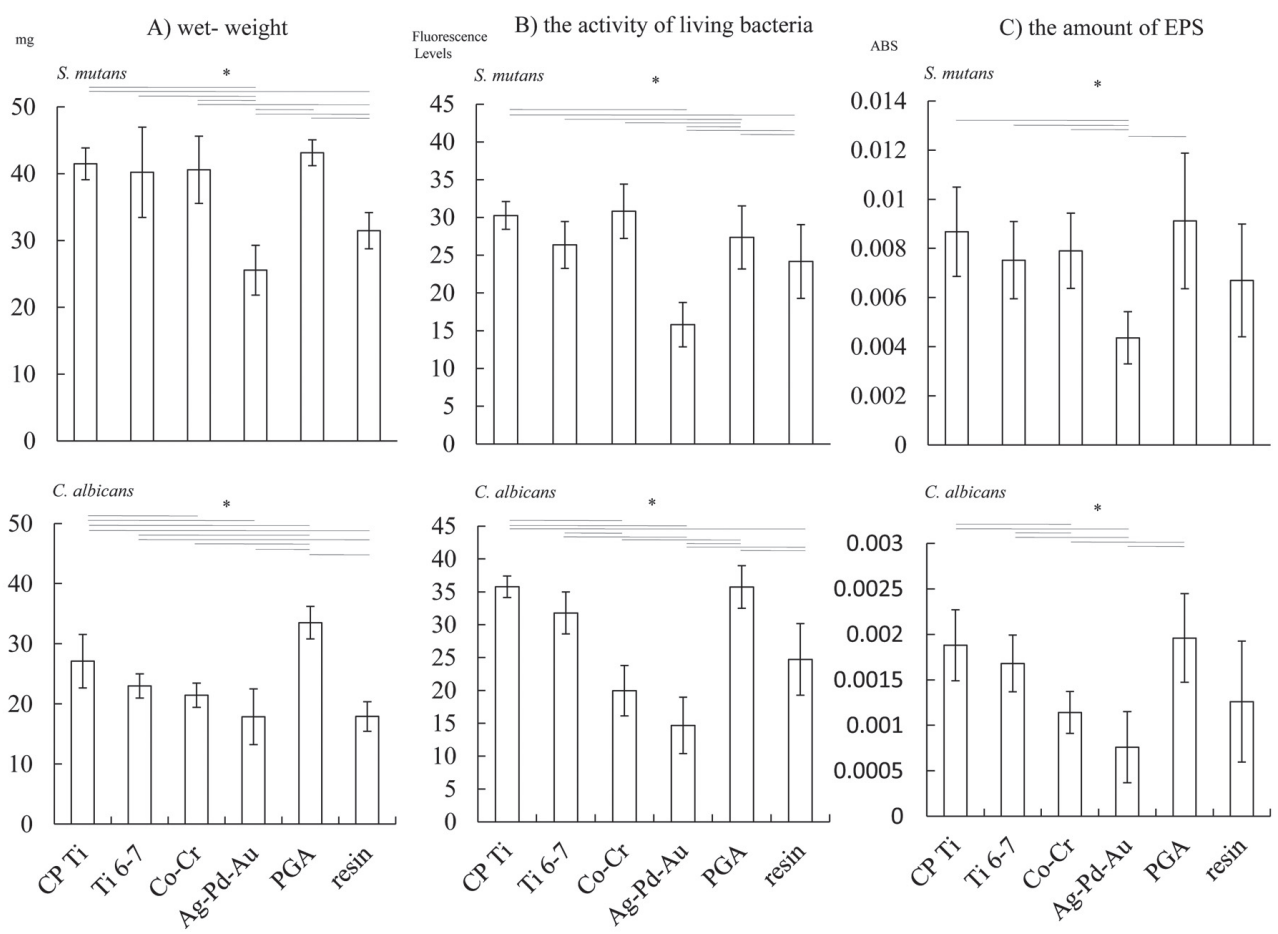

Fig. 8 The determination of the amounts of $S$. mutans or C. albicans adhered to each alloy. After immersion in the filtered pooled saliva overnight, the alloy samples were immersed in the $S$. mutans or $C$. albicans culture suspension and cultivated for one day. The wet-weight of the adherent biofilm, the activity of living bacteria and the amount of dye inclusion were assessed to indicate the levels of $S$. mutans and C. albicans adhered to the samples. The asterisk indicates a significant difference (Mann-Whitney U-test, $p<0.05$ ). A: The wet-weight of the adherent biofilm; the vertical axis shows the increase in the weight, B: The activity of living bacteria; the vertical axis shows the fluorescence level of the metabolized redox indicator $(\times 1000), C$ : The amount of EPS, indicating the levels of biofilm adherence; the vertical axis shows the absorbance at $562 \mathrm{~nm}$ by $S$. mutans and C. albicans

approximately in the order of $\mathrm{PGA}=\mathrm{CP} \mathrm{Ti}>\mathrm{Ti} 6-7>$ $\mathrm{Co}-\mathrm{Cr}>\mathrm{Ag}-\mathrm{Pd}$-Au from day 1 until day 4. However, the differences disappeared on day 7 , except for the finding that Ag-Pd-Au still had the lowest values.

We expected that the resin used as a control would have more adherence by biofilms than alloy samples, because resin is thought to be easily absorbed by denture plaque ${ }^{17)}$. However, to our surprise, the amount of adherent biofilm on the resin sample was significantly lower than that of all of the alloys except Ag-Pd-Au on both overnight and day $4(p<0.05)$. Kawai et al. previously reported the resin monomer has antimicrobial effects against oral bacteria ${ }^{49}$. There was another report indicating that the monomer was mostly eluted within $24 \mathrm{~h}$ after polymerization. However, the small amount of remaining monomer eluted gradually even with immersion for $24 \mathrm{~h}$, and some monomer persisted for several years ${ }^{50}$. The results for the resin were therefore considered to reflect the present of the remaining monomer, which decreased the biofilm adherence on the resin surface. The significant difference between the resin and the other alloys was lost on day 7 (Fig. 3), which may have reflected the loss of a large amount of the remaining monomer.

The quantitative analyses of the biofilms on the framework alloys indicated that there were differences in the amount of adhesion on each alloy until day 4, however, those differences were lost by day 7 .

\section{Observation of the surface of the samples}

Although the contact angle of all samples was the same, some differences in the surfaces of each sample were observed on the SEM images. Especially, no salivary substances were confirmed on the surface of Ag-Pd-Au (Fig. 2a). The components of the salivary substance were thought to be proteins. Because the surface of materials exposed to the oral environment is directly converted by the spontaneous adsorption of protein-dominated films ${ }^{51,52)}$. The amount and composition of such protein might have affected the amount of the biofilm. In addition, calcium ion participated in the attachment among alloy surface, saliva protein and bacteria ${ }^{53,54}$. 
The amount of calcium on the surface of PGA by EPMA images was larger than that seen in other samples (Fig. $2 \mathrm{~b})$. Further investigations to clarify the differences affecting the amount of biofilm on the PGA are thus called for.

Due to the observed differences in the saliva protein attached to the surfaces, and also in the degree of biofilm formation, it might be necessary to analyze the composition of the saliva protein attached to each sample.

\section{Qualitative analyses of biofilms on the samples}

A qualitative analysis was performed to examine the differences in the microbial components present in the biofilms. Recently, new molecular biology techniques have made it possible to perform a metagenomic analysis of the bacterial flora, including the nonculturable bacteria. For these metagenomic analyses, denaturing gradient gel electrophoresis (DGGE) terminal restriction fragment length polymorphisms $(T-R F L P)^{55)}$, next generation sequencing ${ }^{56)}$ and the clone library technique ${ }^{57)}$ are usually performed. Sakamoto et al. previously analyzed the oral bacterial flora, with non-culturable species, from patients with periodontal disease using the T-RFLP method, and compared the findings before and after periodontal treatments ${ }^{55}$. They showed that the sensitivity and specificity of the T-RFLP method were almost the same as those of realtime PCR of the 16SrDNA clone library, but the T-RFLP method was more reliable, because the apparatus can be automated by using capillary electrophoresis, and the reproducibility of the results is higher than that of the DGGE method ${ }^{58}$. Another advantage of T-RFLP is that it makes it possible to comprehensively predict the component species in the bacterial flora. Therefore, we used the T-RFLP method to analyze the bacterial components of the biofilms using an in vitro denture plaque model.

The peak area pattern of T-RFLP revealed that the ratio of bacterial species attached to the $\mathrm{Co}-\mathrm{Cr}$ was different compared to that of the other alloys (Fig. 5). We performed a cluster analysis using the results of the T-RFLP fragments to determine the similarity of the patterns. The pattern of $\mathrm{Co}-\mathrm{Cr}$ was unique in spite of using saliva samples from different individuals, and accumulated in cluster I (Fig. 6). In contrast, CP Ti, Ti 6-7 and resin showed different results for the different saliva samples. The results of the cluster analysis showed that the clade distance of $\mathrm{CP} \mathrm{Ti}, \mathrm{Ti} \mathrm{6-7}$ and resin indicated that they were neighbors. Those results were similar to those of an investigation of the bacterial community on an implant abutments model reported by Yamane et al.23)

The cluster analysis allowed the relationship of the whole variations of microbes to be visualized by comparing the similarity of all samples, and these findings could be summarized in a dendrogram. However, there are pros and cons to studies where the basis of non-similarity where the euclidean distance is based on a cluster analysis ${ }^{59}$. Therefore, we also carried out a Bray-Curtis analysis, because it reflects the nature of the difference between subjects ${ }^{60}$. The Bray-Curtis analysis of the T-RFLP results showed that there was high similarity of T-RFLP profiles of CP Ti, Ti 6-7 and resin. These results suggest that those materials have similar levels of bacterial attachment (Fig. 7). However, there was limited similarity among $\mathrm{CP} \mathrm{Ti}$, Ti 6-7 and resin and the saliva samples themselves (non-similarity shown by the Bray-Curtis index=0.5). This result indicated that only some limited bacteria in the saliva samples might adhere to the alloys and resin.

When the signal data for three degradation enzymes was matched, the accuracy of the estimation might have been increased, and the database ${ }^{41)}$ of bacterial species might have better correspond to the T-RFLP pattern. Therefore, a principal component analysis of the T-RFLP profiles was performed for the three enzymes (date not shown). The results of the principal component analysis, which was performed in silico using statistical data and an estimate based on the ratio, showed the possibility that area 33 might contain Neisseria and/or Haemophilus. Area 33 was the most abundant peak in all samples (Fig. 5). This suggests that the predominant bacteria in all samples might be Nisseria and/or Haemophilus. Teles et al. previously reported that Nisseria was the dominant species in the dental plaque on denture teeth, as well as on natural teeth $^{61}$. Zhu et al. also reported the same finding in saliva, dental plaque and residual ridge ${ }^{3)}$. Ritz described the process of plaque maturation from the initial adhesion $^{62)}$. During this process, Neisseria comprised only $10 \%$ of the early plaque. The discrepancy between the report by Ritz et al. and the studies by Teles, Xhu and our present findings might be explained by the fact that they used only the culture technique. It seems worthwhile to re-examine the normal oral bacterial flora using a metagenomic analysis, because it allows for easier identification of the flora, including bacteria that are difficult or impossible to culture.

The qualitative PCR analysis using the genus- or species-specific primers was carried out to confirm whether the species narrowed down from the database ${ }^{41)}$ truly corresponded to the T-RF of the five alloys and resin. The results of the PCR analysis for the five alloys and the resin sample showed that several microorganisms associated with aspiration pneumonia, including genera of Actinomyces, Fusobacterium, Haemophilus, Mycoplasma and Peptostreptococcus (Table 2), existed in the biofilms formed on the five alloys and resin. The results of the species-specific PCR showed that $P$. gingivalis, $P$. intermedia, $T$. denticola and $T$. forsythia, all periodontal pathogens, were also identified in the five alloys and resin samples. These results revealed that various clinically-relevant pathogens attached to the five alloys and resin after just an overnight immersion in saliva. Yasui et al. revealed that $A$. actinomycetemcomitans, $P$. intermedia, $P$. gingivalis, T. denticola, T. forsythia and Fusobacterium nucleatum were found in the resin denture plaque by $\mathrm{PCR}^{9)}$. Moreover, Sumi et al. reported the colonization 
of respiratory pathogens in denture plaques ${ }^{5,6}$. These reports confirm the importance of denture cleaning to prevent the adherence of these pathogens. Interestingly, the binding properties or affinities of Mycoplasma, $P$. gingivalis and $T$. denticola to the five alloys was shown to be diverse. This result suggested that bacteria adhered selectively to each alloy.

The adhesion properties of $S$. mutans and C. albicans to the framework alloys

There have been many studies on the adhesion of S. mutans and C. albicans to resin ${ }^{1,2,12,13,63)}$, but few reports about their adhesion to the framework alloys. $C$. albicans increases after wearing dentures, and becomes the major pathogen responsible for denture stomatitis. There was a previous report that showed that the level of $S$. mutans, a highly cariogenic bacterium ${ }^{15,16)}$, also increased after wearing dentures ${ }^{3}$. Therefore, we conducted a quantitative analysis of the initial adherence of C. albicans or S. mutans using our in vitro model.

The adhesion level of C. albicans showed the same tendency as the adherence level of biofilms using unfiltrated saliva alone $(\mathrm{PGA}=\mathrm{CP} \mathrm{Ti}>\mathrm{Ti}$ 6-7 $>\mathrm{Co}-\mathrm{Cr}>\mathrm{Ag}$ $\mathrm{Pd}-\mathrm{Au}$ ). On the contrary, the adhesion level of $S$. mutans showed a different tendency, where the adherence to Co$\mathrm{Cr}$ was almost the same as that to PGA and CP Ti (Fig. 8). This result suggested that $S$. mutans preferentially adhered to Co-Cr, PGA and CP Ti. Zhu et al. reported that $S$. mutans increased in the oral cavity after wearing dentures made of $\mathrm{Co}_{-} \mathrm{Cr}^{3)}$, which was similar to our present results. The initial adhesion of C. albicans or S. mutans to Ag-Pd-Au was lower than that to PGA and $\mathrm{CP} \mathrm{Ti}$, as well as the results of the adhesion experiments with saliva. The reason for this low adhesion rate on $\mathrm{Ag}-\mathrm{Pd}-\mathrm{Au}$ was likely due to the fact that the silver ions $^{64)}$ and/or the presence of less salivary protein prevented the adhesion and growth of bacteria (Fig. 2a). However, further studies are called for to clarify this phenomenon.

\section{Factors affecting the adhesion of biofilms to the framework alloys}

The alloys used in this study were divided into two groups, the precious metals included PGA and Ag-Pd$\mathrm{Au}$, and the base metals included $\mathrm{CP} \mathrm{Ti}$, Ti 6-7 and Co-Cr, which formed passive films on the surface. The PGA used in this study contained $70 \% \mathrm{Au}$ that was specifically bond by the disulfide group ${ }^{65}$. The observed phenomenon strongly suggested that the salivary proteins or peptides comprising disulfide ions can become interposed on the surface of the PGA. In contrast, a specific passive film of titanium, which is well known to cause osseointegration, has a negative electric charge at near-neutral $\mathrm{pH}$, and can bind with positive ions such as calcium. The affinity for tissue calcium ions is thought to be related to the attachment of protein onto the surface of titanium ${ }^{54)}$, although the present EPMA analysis could not confirm the adsorption of calcium ion.

The amount of biofilm form on Ti 6-7 was less than that on $\mathrm{CP} \mathrm{Ti}$. The reason for the difference between
Ti 6-7 and CP Ti might be due to the differences in the passive film. Kelly et al. showed that a passive film on titanium $6 \mathrm{Al}-4 \mathrm{~V}$ consisted of titanium and aluminum ${ }^{66)}$. The passive film of Ti 6-7 may contain aluminum, because Ti 6-7 contains both aluminum and niobium. This aluminum might affect the biofilm formation in a manner similar to that in the passive film of titanium $6 \mathrm{Al}-4 \mathrm{~V}$. Further investigation is necessary to clarify the component(s) of the passive film formed on Ti 6-7.

On the other hand, the passive film formed by CoCr has a small deflection of the charge due to close to neutral at $\mathrm{pH} 7.0^{67)}$. The relative permittivity can affect the changes in the conformation of proteins ${ }^{68}$. The relative permittivity level of the passive film on the Co$\mathrm{Cr}$ is considerably lower compared to that of titanium. Therefore, the level of adherent biofilm on the Co-Cr was lower than that on CP Ti or Ti 6-7 (Fig. 3). However, the level of $S$. mutans adherence was almost the same among these three alloys (Fig. 8).

There is a possibility that the composition of the pellicle proteins on the alloys may be different, because they had different isoelectric points. The amino acid composition of denture pellicles was clearly different from those of dental pellicles ${ }^{69}$. Therefore, the biofilm form on the different pellicles might be different for different types of samples. In addition, it has been suggested that the adhesion of bacteria is affected by various factors, such as the differences in the charge of the surface layer of the bacteria ${ }^{70)}$, van der Walls and electrostatic forces, hydrophobicity and the presence of lectin ligands ${ }^{71)}$. Another study will be necessary to understand the reasons why $S$. mutans adhered more to $\mathrm{Co}-\mathrm{Cr}$ than the other alloys.

The results of this study showed that a lot of denture biofilm was attached to the framework alloys. Yamane et al. reported ${ }^{23)}$ that the inter-material differences in the amount of bacteria were smaller than the inter-individual differences in saliva by an in vivo study. However, our results showed that there were significant inter-material differences among the framework alloys. This discrepancy might be explained by the differences in experiment models, the kinds of alloy samples and the maturation status of the biofilms. A further in vivo study would be needed to clarify the differences among the framework alloys.

\section{CONCLUSION}

In conclusion, we made the following findings:

1. The quantitative analysis revealed that the amount of biofilm with total bacteria from saliva or S. mutans or C. albicans formed on the $\mathrm{CP} \mathrm{Ti}$ and PGA was almost the same or higher than that formed on the resin surface, while that form on the Ag-Pd-Au was lower than that on the resin.

2. The qualitative analysis of the biofilms by T-RFLP suggested that the bacterial components in the biofilms were diverse, and varied widely among the framework alloys.

3. Oral microorganisms associated with caries, 
periodontal disease, aspiration pneumonia and systemic diseases were contained in the biofilms adhered to the framework alloys and resin.

4. It was suggested that some pathogenic bacteria adhered selectively to each alloy.

Based on these results, the quantitative and qualitative properties of the biofilms adhered on the framework alloys were determined.

\section{REFERENCES}

1) Campos MS, Marchini L, Bernardes LA, Paulino LC, Nobrega FG. Biofilm microbial communities of denture stomatitis. Oral Microbiol Immunol 2008; 23: 419-424.

2) Nikawa H, Hamada T, Yamamoto T. Denture plaque — past and recent concerns. J Dent 1998; 26: 299-304.

3) Zhu X, Wang S, Gu Y, Li X, Yan H, Miyoshi S, Shi L. Possible variation of the human oral bacterial community after wearing removable partial dentures by DGGE. World $J$ Microbiol Biotechnol 2012; 28: 2229-2236.

4) Narikiyo M, Tanabe C, Yamada Y, Igaki H, Tachimori $Y$, Kato H, Muto M, Montesano R, Sakamoto H, Nakajima Y, Sasaki H. Frequent and preferential infection of Treponema denticola, Streptococcus mitis, and Streptococcus anginosus in esophageal cancers. Cancer Sci 2004; 95: 569-574.

5) Sumi Y, Miura H, Sunakawa M, Michiwaki Y, Sakagami N. Colonization of denture plaque by respiratory pathogens in dependent elderly. Gerodontology 2002; 19: 25-29.

6) Sumi Y, Kagami H, Ohtsuka Y, Kakinoki Y, Haruguchi Y, Miyamoto H. High correlation between the bacterial species in denture plaque and pharyngeal microflora. Gerodontology 2003; 20: 84-87.

7) Abridged life tables for Japan 2012[Internet]. IV. Analysis by cause of death. Statistics and information department, minister's secretariat, Ministry of health, labour and welfare, Government of Japan. [cited 2013 Jul 25]. Available from: http://www.mhlw.go.jp/english/database/db-hw/lifetb12/dl/ lifetb12-04.pdf

8) Kwong JC, Howden BP, Charles PG. New aspirations: the debate on aspiration pneumonia treatment guidelines. Med $\mathrm{J}$ Aust 2011; 195: 380-381.

9) Yasui M, Ryu M, Sakurai K, Ishihara K. Colonisation of the oral cavity by periodontopathic bacteria in complete denture wearers. Gerodontology 2012; 29: e494-502.

10) El-Solh AA. Association between pneumonia and oral care in nursing home residents. Lung 2011; 189: 173-180.

11) Scannapieco FA, Papandonatos GD, Dunford RG. Associations between oral conditions and respiratory disease in a national sample survey population. Ann Periodontol 1998; 3: 251-256.

12) Chandra J, Mukherjee PK, Leidich SD, Faddoul FF, Hoyer LL, Douglas LJ, Chandra J, Mukherjee PK, Leidich SD, Faddoul FF, Hoyer LL, Douglas LJ, Ghannoum MA. Antifungal resistance of candidal biofilms formed on denture acrylic in vitro. J Dent Res 2001; 80: 903-908.

13) Arendorf TM, Walker DM. Denture stomatitis: a review. J Oral Rehabil 1987; 14: 217-227.

14) Gendreau L, Loewy ZG. Epidemiology and etiology of denture stomatitis. J Prosthodont 2011; 20: 251-260.

15) Kohler B, Andreen I, Jonsson B. The earlier the colonization by mutans streptococci, the higher the caries prevalence at 4 years of age. Oral Microbiol Immunol 1988; 3: 14-17.

16) Gaines S, James TC, Folan M, Baird AW, O'Farrelly C. A novel spectrofluorometric microassay for Streptococcus mutans adherence to hydroxylapatite. J Microbiol Methods 2003; 54: 315-323.

17) Hashiguchi M, Nishi $Y$, Kanie $T$, Ban S, Nagaoka E. Bactericidal efficacy of glycine-type amphoteric surfactant as a denture cleaner and its influence on properties of denture base resins. Dent Mater J 2009; 28: 307-314.

18) Regli CH, Kydd WL. A preliminary study of the lateral deformation of metal base dentures in relation to plastic base dentures. J Prosthet Dent 1953: 326-330.

19) Ohkubo C, Hanatani S, Hosoi T. Present status of titanium removable dentures $-\mathrm{a}$ review of the literature. J Oral Rehabil 2008; 35: 706-714.

20) Kononen M, Rintanen J, Waltimo A, Kempainen P. Titanium framework removable partial denture used for patient allergic to other metals: a clinical report and literature review. J Prosthet Dent 1995; 73: 4-7.

21) Nakajima H, Okabe T. Titanium in dentistry: development and research in the U.S.A. Dent Mater J 1996; 15: 77-90.

22) Muraisi E. Retentive forces and fitting accuracy of repaired akers clasps using laser welding. Tsurumi Univ Dent 2010; 36: 53-65.

23) Yamane K, Ayukawa Y, Takeshita T, Furuhashi A, Yamashita Y, Koyano K. Bacterial adhesion affinities of various implant abutment materials. Clin Oral Implants Res 2013; 24. 13101315.

24) Rasperini G, Maglione M, Cocconcelli P, Simion M. In vivo early plaque formation on pure titanium and ceramic abutments: a comparative microbiological and SEM analysis. Clin Oral Implants Res 1998; 9: 357-364.

25) Kawai Y. Study of polishing steps for Titanium castings. Tsurumi Univ Dent J 1997; 23: 407-418.

26) Mukumoto M, Ohshima T, Ozaki M, Konishi H, Maeda N, Nakamura Y. Effect of microbubbled water on the removal of a biofilm attached to orthodontic appliances -an in vitro study. Dent Mater J 2012; 31: 821-827.

27) Takeshita T, Nakano Y, Yamashita Y. Improved accuracy in terminal restriction fragment length polymorphism phylogenetic analysis using a novel internal size standard definition. Oral Microbiol Immunol 2007; 22: 419-428.

28) Xia T, Baumgartner JC. Occurrence of actinomyces in infections of endodontic origin. J Endod 2003; 29: 549-552.

29) Salles JF, De Souza FA, van Elsas JD. Molecular method to assess the diversity of Burkholderia species in environmental samples. Appl Environ Microbiol 2002; 68: 1595-1603.

30) Nagano Y, Watabe M, Porter KG, Coulter WA, Millar BC, Elborn JS, Goldsmith CE, Rooney PJ, Loughrey A, Moore JE. Development of a genus-specific PCR assay for the molecular detection, confirmation and identification of Fusobacterium spp. Br J Biomed Sci 2007; 64: 74-77.

31) Matar G M, Khoudoud V A, Fayad M, Mikati M. Abdelnoor A M. A two-step protocol for the identification of the etiology of bacterial meningitis in cerebrospinal fluid by PCR amplification of the 16s ribosomal RNA gene. Eastern Journal of Medicine 1999; 4: 27-31.

32) Lierz M, Hagen N, Harcourt-Brown N, Hernandez-Divers SJ, Luschow D, Hafez HM. Prevalence of mycoplasmas in eggs from birds of prey using culture and a genus-specific mycoplasma polymerase chain reaction. Avian Pathol 2007; 36: $145-150$.

33) Lansac N, Picard FJ, Menard C, Boissinot M, Ouellette M, Roy PH, Bergeron MG. Novel genus-specific PCR-based assays for rapid identification of Neisseria species and Neisseria meningitidis. Eur J Clin Microbiol Infect Dis 2000; 19: $443-451$.

34) Song Y, Liu C, McTeague M, Vu A, Liu JY, Finegold SM. Rapid identification of Gram-positive anaerobic coccal species originally classified in the genus Peptostreptococcus by multiplex PCR assays using genus- and species-specific primers. Microbiology 2003; 149: 1719-1727.

35) Wagner J, Short K, Catto-Smith AG, Cameron DJ, Bishop $\mathrm{RF}$, Kirkwood CD. Identification and characterisation of Pseudomonas 16S ribosomal DNA from ileal biopsies of children with Crohn's disease. PLoS One 2008; 3: e3578.

36) Picard FJ, Ke D, Boudreau DK, Boissinot M, Huletsky A, 
Richard D, Ouellette M, Roy PH, Bergeron MG. Use of tuf sequences for genus-specific PCR detection and phylogenetic analysis of 28 streptococcal species. J Clin Microbiol 2004; 42: 3686-3695.

37) Zhang K, Sparling J, Chow BL, Elsayed S, Hussain Z, Church DL, Gregson DB, Louie T, Conly JM. New quadriplex PCR assay for detection of methicillin and mupirocin resistance and simultaneous discrimination of Staphylococcus aureus from coagulase-negative staphylococci. J Clin Microbiol 2004; 42: 4947-4955.

38) Fujita S, Lasker BA, Lott TJ, Reiss E, Morrison CJ. Microtitration plate enzyme immunoassay to detect PCRamplified DNA from Candida species in blood. J Clin Microbiol 1995; 33: 962-967.

39) Ashimoto A, Chen C, Bakker I, Slots J. Polymerase chain reaction detection of 8 putative periodontal pathogens in subgingival plaque of gingivitis and advanced periodontitis lesions. Oral Microbiol Immunol 1996; 11: 266-273.

40) Rupf S, Merte K, Eschrich K, Stosser L, Kneist S. Peroxidase reaction as a parameter for discrimination of Streptococcus mutans and Streptococcus sobrinus. Caries Res 2001; 35: 258-264.

41) Nakano Y, Takeshita T, Kamio N, Shiota S, Shibata Y, Yasui M, Yamashita Y. Development and application of a T-RFLP data analysis method using correlation coefficient matrices. J Microbiol Methods 2008; 75: 501-505.

42) Teughels W, Van Assche N, Sliepen I, Quirynen M. Effect of material characteristics and/or surface topography on biofilm development. Clin Oral Implants Res 2006; 17: 68-81.

43) Bollen CM, Papaioanno W, Van Eldere J, Schepers E, Quirynen M, van Steenberghe D. The influence of abutment surface roughness on plaque accumulation and peri-implant mucositis. Clin Oral Implants Res 1996; 7: 201-211.

44) Zissis AJ, Polyzois GL, Yannikakis SA, Harrison A. Roughness of denture materials: a comparative study. Int J Prosthodont 2000; 13: 136-140.

45) Frank RM, Steuer P. Transmission electron microscopy of plaque accumulations in denture stomatitis. J Prosthet Dent 1985; 53: 115-124.

46) Bollen CM, Lambrechts P, Quirynen M. Comparison of surface roughness of oral hard materials to the threshold surface roughness for bacterial plaque retention: a review of the literature. Dent Mater 1997; 13: 258-269.

47) Quirynen M, Bollen CM. The influence of surface roughness and surface-free energy on supra- and subgingival plaque formation in man. A review of the literature. J Clin Periodontol 1995; 22: 1-14.

48) Quirynen M, Bollen CM, Papaioannou W, Van Eldere J, van Steenberghe D. The influence of titanium abutment surface roughness on plaque accumulation and gingivitis: short-term observations. Int J Oral Maxillofac Implants 1996; 11: 169178.

49) Kawai K. Effect of Eluares from Composite resins on GTase and Growth of Streptococcus mutans. Jpn J Conserv Dent 1988; 31: 332-351.

50) Singh RD, Gautam R, Siddhartha R, Singh BP, Chand P, Sharma VP, Jurel SK. High performance liquid chromatographic determination of residual monomer released from heat-cured acrylic resin. An in vivo study. J Prosthodont 2013; 22: 358-361.

51) Lamkin MS, Arancillo AA, Oppenheim FG. Temporal and compositional characteristics of salivary protein adsorption to hydroxyapatite. J Dent Res 1996; 75: 803-808.
52) Lendenmann U,Grogan J,Oppenheim FG. Saliva and dental pellicle —a review. Adv Dent Res 2000; 14: 22-28.

53) Rosan B. In: Slots J and Taubman A M, editor. Contemporary oral microbiology and immunology. St. Louis: Mosby Year Book; 1992. p. 283-298.

54) Hanawa T, Ota M. Calcium phosphate naturally formed on titanium in electrolyte solution. Biomaterials 1991; 12: 767774.

55) Sakamoto M, Huang Y, Ohnishi M, Umeda M, Ishikawa I, Benno Y. Changes in oral microbial profiles after periodontal treatment as determined by molecular analysis of $16 \mathrm{~S}$ rRNA genes. J Med Microbiol 2004; 53: 563-571.

56) Boutin S, Audet C, Derome N. Probiotic treatment by indigenous bacteria decreases mortality without disturbing the natural microbiota of Salvelinus fontinalis. Can J Microbiol 2013; 59: 662-670.

57) Koyanagi T, Sakamoto M, Takeuchi Y, Ohkuma M, Izumi Y. Analysis of microbiota associated with peri-implantitis using 16S rRNA gene clone library. J Oral Microbiol 2010; doi: 10.3402/jom.v2i0.5104.

58) Prabhakar A, Bishop AH. Comparative studies to assess bacterial communities on the clover phylloplane using MLST, DGGE and T-RFLP. World J Microbiol Biotechnol 2014; 30. 153-161.

59) Clarke K R, Ainsworth M. A method of linking multivariate community structure to environmental variables. Mar Ecol Prog Ser 1993; 92: 205-219.

60) Faith P D, Minchin P R, Belbin L. Compositional dissimilarity as a robust measure of ecological distance. Vegetatio 1987; 69: 57-68.

61) Teles FR, Teles RP, Sachdeo A, Uzel NG, Song XQ, Torresyap G, Singh M, Papas A, Haffajee AD, Socransky SS. Comparison of microbial changes in early redeveloping biofilms on natural teeth and dentures. J Periodontol 2012; 83: 1139-1148.

62) Ritz HL. Microbial population shifts in developing human dental plaque. Arch Oral Biol 1967; 12: 1561-1568.

63) Buergers R, Rosentritt M, Handel G. Bacterial adhesion of Streptococcus mutans to provisional fixed prosthodontic material. J Prosthet Dent 2007; 98: 461-469.

64) Uchida M, Yamamoto T, Furuhashi H, Nakata S, Nakagawa Z. Antibacterial activity of silver ions at a minimum inhibitory concentration. J Antibact Antifung Agents 2004; 32: 115-121.

65) Ulman A. Formation and structure of self-assembled monolayers. Chem Rev 1996; 96: 1533-1554.

66) Kelly E J. In: O’M Bockris Conway J. White E. B, Ralph E, editor. Modern aspects of electrochemistry. New York: Plenum Press; 1982. p. 319-424.

67) Parfitt GD. In: Parfitt GD, Sing KSW, editor. Progress of surface of membrane science. New York: Academic Press; 1976. p. 181-226.

68) Ivarsson B, Lundstrom. In: Williams DF, editor. CRC critical reviews in biocompatibility. Boca Raton FL: CRC press; 1986. p. 1-96.

69) Lendenmann U, Grogan J, Oppenheim FG. Saliva and dental pellicle —a review. Adv Dent Res 2000; 14: 22-28.

70) van der Mei HC, de Soet JJ, de Graaff J, Rouxhet PG, Busscher HJ. Comparison of the physicochemical surface properties of Streptococcus rattus with those of other mutans streptococcal species. Caries Res 1991; 25: 415-423.

71) Cowan MM, Taylor KG, Doyle RJ. Kinetic analysis of Streptococcus sanguis adhesion to artificial pellicle. J Dent Res 1986; 65: 1278-1283. 